\title{
Anuran captured in pitfall traps in three agrossystem in Northwestern São Paulo State, Brazil
}

\author{
Fernando Rodrigues da Silva ${ }^{1,5}$, Rodrigo Souza Santos ${ }^{2}$, \\ Maria Andréia Nunes ${ }^{3}$ \& Denise de Cerqueira Rossa-Feres ${ }^{4}$ \\ ${ }^{1}$ Programa de Pós Graduação em Biologia Animal, Campus de São José do Rio Preto, \\ Universidade Estadual Paulista - UNESP, \\ Rua Cristóvão Colombo, 2265, Jd. Nazareth, CEP 15054-000, São José do Rio Preto, SP, Brazil \\ ${ }^{2}$ Faculdades Integradas - FACVEST, \\ Av. Marechal Floriano, 947, Centro, CEP 88501-103, Lages, SC, Brazil, e-mail: santos_rss@hotmail.com \\ ${ }^{3}$ Campus de Jaboticabal, Universidade Estadual Paulista - UNESP, \\ Jaboticabal, SP, Brasil, e-mail: mandeian@yahoo.com.br \\ ${ }^{4}$ Departamento de Zoologia e Botânica, Campus de São José do Rio Preto, \\ Universidade Estadual Paulista - UNESP, \\ São José do Rio Preto, SP, Brazil, e-mail: denise@ibilce.unesp.br \\ ${ }^{5}$ Corresponding author: Fernando Rodrigues da Silva, e-mail: bigosbio@yahoo.com.br
}

SILVA, F.R., SANTOS, R.S., NUNES, M.A. \& ROSSA-FERES, D.C. Anuran captured in pitfall traps in three agrossystems in Northwestern São Paulo State, Brazil. Biota Neotrop. 9(4): http://www.biotaneotropica.org. br/v9n4/en/abstract?short-communication+bn01109042009.

\begin{abstract}
Although it is generally assumed that agriculture negatively influences amphibian populations, few studies on the effects of agricultural cultivations on neotropical anuran have been conducted. As a contribution to the knowledge about anuran in agriculture, the present study sought to identify the anuran species present in three different agrossystems. We used data from anurans captured in pitfall traps initially proposed for a survey of harvestmen fauna in three agrossystems (corn, soybean, and rubber tree). Four anuran species found in the pitfall traps belong to two Families: Leptodactylidae: Leptodactulus fuscus and L. mystacinus; and Leiuperidae: Eupemphix nattereri and Physalaemus cuvieri. In corn plantation, four species and 30 individuals were captured; in rubber trees, four species and 11 individuals; and in soybeans plantation, tree species and eight individuals. Our results show that anurans are present in agrossystems, mainly the generalist anuran species.
\end{abstract}

Keywords: amphibian, soybean plantation, corn plantation and rubber tree.

SILVA, F.R., SANTOS, R.S., NUNES, M.A. \& ROSSA-FERES, D.C. Anuros capturados em armadilhas de queda em três agrossistemas no noroeste paulista, Brasil. Biota Neotrop. 9(4): http://www.biotaneotropica. org.br/v9n4/en/abstract?short-communication+bn01109042009.

Resumo: Embora seja geralmente assumido que a agricultura influencia negativamente populações de anfíbios, existem poucos estudos sobre os efeitos dos cultivos agrícolas em anuros neotropicais. Visando contribuir para diminuir essa lacuna de conhecimento,no presente estudo buscamos verificar quais espécies de anuros estão presentes nos agrossistemas. Para isso, usamos dados de anuros capturados em armadilhas de queda, inicialmente proposto para o levantamento da fauna de opiliões em três agrossistemas (milho, soja e seringal). Nós registramos quatro espécies de anuros nas armadilhas de queda: Leptodactulus fuscus, L. mystacinus (Leptodactylidae), Eupemphix nattereri e Physalaemus cuvieri (Leiuperidae). Na plantação de milho foram registradas quatro espécies e 30 indivíduos, no seringal quatro espécies e 11 indivíduos e na plantação de soja três espécies e oito indivíduos. Nossos resultados mostram que os anuros estão presentes nos agrossistemas, principalmente espécies de anuros generalistas.

Palavras-chave: anfíbios, plantação de soja, plantação de milho e seringal. 


\section{Introduction}

Habitat loss and fragmentation are among the largest threats to amphibian populations (Cushman 2006). One of the main causes of anthropogenic habitat loss is agricultural intensification, which has impacted negatively the species diversity and abundance of amphibians (Hecnar \& M'Closkey 1996, Semlitsch 2000, Knutson et al. 2004). Several studies conducted in North America have examined the effects of agrossystems on anuran (Semlistch 2000, Gray et al. 2004, Knutson et al. 2004, Weyrauch \& Grubb Jr. 2004, Gardner et al. 2007). However, few data are available for South America (Attademo et al. 2005, Peltzer et al. 2006, Faria et al. 2007, Pardini et al. 2009) and consequently, such effects remain undocumented for most neotropical anurans (Gardner et al. 2007). In this study, we sought to identify the anuran species present in agrossystems in northwestern São Paulo State, Brazil. We used data from anurans captured in pitfall traps initially proposed for a survey of harvestmen fauna in three different agrossystems (corn, soybean, and rubber tree).

\section{Material and Methods}

The sample design was initially proposed by Santos \& Cividanes (2007) to the survey of harvestmen fauna in agrossystems. However, the number of anuran species and individuals captured in small pitfalls was surprisingly high, thus providing information on the presence of anurans in agrossystems. This study was conducted at the Study, Research and Production Farm, College for Animal and Crop Production (FCAV/UNESP - Fazenda de Estudo, Pesquisa e Produção, Faculdade de Ciências Agrárias e Veterinárias), Jaboticabal (21 ${ }^{\circ} 15^{\prime} \mathrm{S}$ and $48^{\circ} 18^{\prime}$ W), São Paulo State, Brazil. The climate in the region is hot and humid tropical (Aw de Köppen), the mean temperature is $22{ }^{\circ} \mathrm{C}$, and the annual total precipitation is $1552 \mathrm{~mm}$ (Sacramento \& Pereira 2003).

Anurans were sampled with pitfall traps, installed in three agrossystem (corn, soybean, and rubber tree). Each area had two parallel, $90 \mathrm{~m}$ long transects $10 \mathrm{~m}$ apart from each other. Each transect had ten equidistant (every $10 \mathrm{~m})$ white plastic cups $(500 \mathrm{~mL})$ filled with $1 \%$ formaldehyde solution and a few drops of neutral detergent. For more details about pitfall traps, see Santos \& Cividanes (2007). Fieldwork was performed every week, totaling 13 samples from each agrossystems, during the rainy season (December $27^{\text {th }} 2004$ to April $2^{\text {nd }} 2005$ ), with a total effort of 97 days. Used plastic cups were replaced by new ones after each survey.

Individuals were deposited in the Amphibian Collection (DZSJRP 8286 - 8289; 8291 - 8300; 8316 - 8320; 8323 - 8326; $8328 ; 8331 ; 8343$ - 8344; 8346; 8352 - 8374), Departamento de Zoologia e Botânica, Universidade Estadual Paulista, São Paulo, Brasil (http://splink.cria.org.br/manager/detail?resource=DZSJRPAmphibia-adults\&setlang=pt).

\section{Results and Discussion}

We recorded four anuran species in the pitfall traps, belonging to two Families: Leptodactylidae: Leptodactulus fuscus (Schneider 1799) and L. mystacinus (Burmeister 1861); Leiuperidae: Eupemphix nattereri Steindachner 1863 and Physalaemus cuvieri Fitzinger 1826 (Table 1). Four species and 30 individuals were captured in corn plantation; in rubber trees, four species and 11 individuals; and in soybeans, three species and eight individuals (Table 1). Two individuals of Scinax fuscovarius (Lutz 1925) were registered in artificial shelters built with planks of wood (Parmelee \& Fitch $1995)$ of $1,0 \times 1,0 \mathrm{~m}$, filled with leaves, litter and small stones in corn plantation. Three species of generalist habits (Toledo et al. 2003, Santos et al. 2007), Leptodactylus mystacinus, Physalaemus
Table 1. Anuran species captured in pitfall traps installed in three different agrossystems (corn, rubber trees, and soybeans) in the municipality of Jaboticabal, SP, Brazil.

Tabela 1. Espécies de anuros capturados nas armadilhas de queda instaladas em três diferentes agrossistemas (milho, seringal e soja) no município de Jaboticabal, SP, Brasil.

\begin{tabular}{lrcc}
\hline & Corn & Rubber tree & Soybean \\
\hline LEPTODACTYLIDAE & & & \\
Leptodactylus mystacinus & 3 & 3 & 3 \\
Leptodactylus fuscus & 2 & 1 & - \\
LEIUPERIDAE & & & \\
Physalaemus cuvieri & 4 & 1 & 1 \\
Eupemphix nattereri & 21 & 6 & 4 \\
Species richness & 4 & 4 & 3 \\
Abundance & 30 & 11 & 8 \\
\hline
\end{tabular}

cuvieri, and Eupemphix nattereri were recorded for all agrossystems (corn, soybean, and rubber trees). According to Gray et al. (2004), agricultural disturbance around wetlands may positively influence the abundance of some amphibian species. Less vagile amphibians that explosively breed and are competitively dominant in the absence of predation may benefit most by landscape cultivation (Gray et al. 2004), which lead some authors to suggest that anuran populations can be important for the biological control of agricultural arthropods (Attademo et al. 2005).

It is important to emphasize that pitfall traps with drift fence are often used for sampling amphibians in hepertofauna studies (Heyer et al. 1994, Cechin \& Martins 2000, Dixo \& Verdade 2006, Santos et al. 2009). However, the $500 \mathrm{~mL}$ traps used in our study are much smaller than those normally used (20,000 to $100,000 \mathrm{~mL})$. In addition, the lack of drift fences to connect the traps limited the number of species that can be captured in agrossystems - e.g. Rhinella schneideri (Werner 1894) which is a very common species in the sampling area.

Any interpretation of our results is limited due to the sampling design, small trap-size and the lack of crop replicates. Nonetheless, $65.6 \%$ of the specimens we captured in corn plantation were Eupemphix nattereri. We thus present two non-exclusive hypotheses to be tested:

i) Eupemphix nattereri is a burrowing frog (Sazima 1975, Freitas 2001) associated with the plant root system and respective soil type, helping E. nattereri to remain burrowed until the following reproductive season; and/or

ii) E. nattereri is a food specialist in Isoptera (Rossa-Feres 1997, Silva 2007) that can use this type of crop to feed. Aquino et al. (2008), found that the community of social insects (Formicidae and Isoptera) was responsible for more than $40 \%$ of the total density in cropping systems at the experimental field of Embrapa Agropecuária Oeste, in Dourados, State of Mato Grosso do Sul, Brazil.

The anuran species found in our study are mainly generalists. This work then contributes to the preliminary knowledge of anurans in Neotropical agrossystems, but further studies and surveys must be done to understand the influence of agrossystems on anuran population parameters (abundance and temporal occurrence) and richness in the region.

\section{References}

AQUINO, A.M., SILVA, R.F., MERCANTE, F.M., CORREIA, M.E.F., GUIMARÃES, M.F. \& LAVELLE, P. 2008. Invertebrate soil macrofauna 
under different ground cover plants in the no-till system in the Cerrado. Eur. J. Soil Biol. 44:191-197.

ATTADEMO, A.M., PELTZER, P.M. \& LAJMANOVICH, R.C. 2005. Amphibians occurring in soybean and implications for biological control in Argentina. Agri. Eco. Environ. 106:389-394.

CECHIN, S.Z. \& MARTINS, M. 2000. Eficiência de armadilhas de queda (pitfall traps) em amostragem de anfíbios e répteis no Brasil. Rev. Bras. Zool. 17(3): 729-740.

CUSHMAN, S.A. 2006. Effects of habitat loss and fragmentation on amphibians: a review and prospectus. Biol. Conserv. 128(2):231-240.

DIXO, M. \& VERDADE, V.K. 2006. Leaf litter herpetofauna of the Reserva Florestal de Morro Grande, Cotia (SP). Biota Neotrop. 6: (2) http://www. biotaneotropica.org.br/v6n2/pt/abstract?article+bn00806022006

GARDNER, T.A., BARLOW, J. \& PERES C.A. 2007. Paradox, presumption and pitfalls in conservation biology: the importance of habitat change for amphibians and reptiles. Biol. Conserv. 138: 166-179.

GRAY, M.J., SMITH, L.M. \& BRENES, R. 2004. Effects of agricultural cultivation on demographics of southern high plains amphibians. Conserv. Biol. 18(5):1368-1377.

FARIA, D., PACIENCIA, M.L.B., DIXO, M., LAPS, R.R. \& BAUMGARTEN, J. 2007. Ferns, frogs, lizards, birds and bats in forest fragments and shade cacao plantations in two contrasting landscapes in the Atlantic forest, Brazil. Biodivers. Conserv. 16:2335-2357.

FREITAS, E.F.L. 2001. Adaptações esqueléticas para a escavação em Leptodactylus fuscus e Physalaemus nattereri (Anura, Leptodactylidae). Master Thesis, UNESP, Botucatu, São Paulo, Brasil.

HECNAR, S. J. \& M'CLOSKEY, R.T. 1996. Regional dynamics and the status of amphibians. Ecology 77:2091-2097.

HEYER, W.R., DONNELLY, M.A., McDIARMID, R.W., HAYEK, L.A.C \& FOSTER. M.S. 1994. Measuring and monitoring biological diversity: Standard methods for amphibians. Smithsonian Institution Press, Washington and London.

KNUTSON, M.G., RICHARDSON, W.B., REINEKE, D.M., GRAY, B.R., PARMELEE, J.R. \& WEICK, S.E. 2004. Agricultural ponds support amphibian populations. Ecol. Appl. 14(3):669-684.

PARDINI, R., FARIA, D., ACCACIO, G.M., LAPS, R.R., MARIANO-NETO, E., PACIENCIA, M.L.B., DIXO, M. \& BAUMGARTEN, J. 2009. The challenge of maintaining Atlantic forest biodiversity: A multi-taxa conservation assessment of specialist and generalist species in an agroforestry mosaic in southern Bahia. Biol. Conserv. 142: 1178-1190.
PARMELLE, J.R. \& FITCH, H.S. 1995. An experiment with artificial shelters for snakes: effects of material, age, and surface preparation. Herpet. Nat. Hist. 3:187-191.

PELTZER, P.M., LAJMANOVICH, R.C., ATTADEMO, A.M. \& BELTZER, A.H. 2006. Diversity of anurans across agricultural ponds in Argentina. Biodivers. Conserv. 15:3499-3513.

ROSSA-FERES, D.C. 1997. Ecologia de uma comunidade de anfíbios anuros da região noroeste do Estado de São Paulo: microhabitat, sazonalidade, dieta e nicho multidimensional. Phd Thesis, UNESP, Rio Claro, São Paulo, Brasil.

SACRAMENTO, C.K. \& PEREIRA, F.M. 2003. Fenologia da floração da nogueira macadâmia (Macadamia integrifolia Maiden \& Betche) nas condições climáticas de Jaboticabal, São Paulo, Brasil. Rev. Bras. Frutic. 25(1): 19-22

SANTOS, R.S. \& CIVIDANES, F.J. 2007. Registro de opiliões (Arachnida: Opiliones) em três agrossistemas e remanescente florestal. Ecossistema 32(1):9-12

SANTOS, T.G., VASCONCELOS, T.S., ROSSA-FERES, D.C. \& HADDAD, C.F.B. 2009. Anurans of a seasonally dry tropical forest: Morro do Diabo State Park, São Paulo state, Brazil. J. Nat. Hist. 43(15): 973-993.

SANTOS, T.G., ROSSA-FERES, D.C., CASATTI, L. 2007. Diversidade e distribuição espaço-temporal de anuros em região com pronunciada estação seca no sudeste do Brasil. Iheringia 97 (1): 37-49.

SAZIMA, I. 1975. Hábitos reprodutivos e fase larvária de Leptodactylus mystacinus e L. sibilatrix (Anura, Leptodactylidae). Master Thesis, University of São Paulo, São Paulo, Brasil.

SEMLITSCH, R.D. 2000. Principles for management of aquatic breeding amphibians. J. Wildlife Manage. 64:615-631.

SILVA, F.R. 2007. A importância de fragmentos florestais na diversidade de anuros em Icém, região noroeste do Estado de São Paulo. Master Thesis, UNESP, São José do Rio Preto, São Paulo, Brasil.

TOLEDO, L.F., ZINA, J. \& HADDAD, C.F.B. 2003. Distribuição espacial e temporal de uma comunidade de anfíbios anuros do Município de Rio Claro, São Paulo, Brasil. Holos Environment 3(2): 136-149.

WEYRAUCH, S.L. \& GRUBB JR, T.C. 2004. Patch and landscape characteristics associated with the distribution of woodland amphibians in an agricultural fragmented landscape: an information-theoretic approach. Biol. Conserv. 115:443-450.
Received: 07/04/09

Revised:19/08/09

Accepted: 20/10/09 